\title{
Great War Shakespeare: Somewhere in France,
} 1914-1919

Ton Hoenselaars

\section{(2) OpenEdition \\ 1 Journals}

\section{Electronic version}

URL: http://journals.openedition.org/shakespeare/2960

DOI: $10.4000 /$ shakespeare. 2960

ISSN: 2271-6424

Publisher

Société Française Shakespeare

\section{Electronic reference}

Ton Hoenselaars, «Great War Shakespeare: Somewhere in France, 1914-1919», Actes des congrès de la Société française Shakespeare [Online], 33 | 2015, Online since 10 March 2015, connection on 04 June 2020. URL : http://journals.openedition.org/shakespeare/2960 ; DOI : https://doi.org/10.4000/ shakespeare.2960

This text was automatically generated on 4 June 2020 .

(c) SFS 


\title{
Great War Shakespeare: Somewhere in France, 1914-1919
}

\author{
Ton Hoenselaars
}

1 This paper investigates relations between France and Britain during the Great War period, and the ways in which the reputation and the work of Shakespeare played a role in these, before and in the course of the Great War, as well as during the traumatic years immediately following the Armistice of 1918. It focuses on a unique moment in history when two more or less traditional enemies - whose cultures are an almost continuing story of this reciprocal antagonism - teamed up, originally in an entente cordiale, and later also in a political and military alliance, to face a third enemy, Germany.

2 In its study of this unique moment in history, this paper devotes special attention to the poems and plays of shakespeare as these were read, performed, mobilised and became a record of the close relationship between France and Britain, providing wisdom and entertainment for those who had to face a war of unprecedented proportions. In doing so, it also challenges the traditional approach to these British and French cultures in isolation. Studying the nations separately ignores the vital fact that behind the military alliance against the Germans, there was still a bilateral entente cordiale. As this paper looks at the fate of Shakespeare during the Anglo-French alliance, it is especially alert to what may be learnt from this unique moment in history about the continuing fortunes of shakespeare in the narrow national and bilateral contexts, as well as the broader European contexts.

When I first set out on my investigation into the relations between France and Britain during the Great War period, and the ways in which these affected and were affected by the reception of Shakespeare, it seemed like a rather vain undertaking. "Shakespeare" is surprisingly absent from the voluminous official Anglo-French history of the Great War. ${ }^{1}$ Even the biographies of the main players have little or nothing to offer. Jonathan Rose's recent study, for example, The Literary Churchill, offers no connections for the First World War. ${ }^{2}$ Matters are different when we turn to Shakespeare in French theatre history or to the modernist writing about the war by Apollinaire and Proust. Although 
no comprehensive study of the subject exists, the field has been amply explored, and we know much about how Shakespeare was performed and commemorated at the Comédie Française, or staged at the Théâtre Antoine where Firmin Gémier (inspired by Max Reinhardt) revolutionized the French stage practice of Shakespeare, and drew attention to himself as the founder in 1917 of the Société Shakespeare.

This French theatre history has been analysed at length, also across national borders. ${ }^{3}$ The same cannot be said of a host of other events, like theatre productions on the English and the French amateur stages across the country, "somewhere in France" as the censor used to put it, for security reasons seeking not to divulge the real place of action. And journals and reviews of the time - kindly obeying the censor - repeated the censor's phrase or variants of it. Less familiar, too, are the materials in the popular press, propaganda releases, cartoons, diaries, letters and other ego-documents. Indeed, there is a tremendous volume of such materials, and this paper relies on a fair amount of them. Yet, it seems worth stressing at the outset that more research into these neglected sources is still desirable, research that is preferably (since it concerns matters of a bilateral kind and of an even broader geographical scope) an international team effort. How better to reason the need, than by trying to demonstrate how a reading of some of these previously neglected sources may invite a reassessment of some generally accepted beliefs about Shakespeare and the Great War, in both an Anglo-French and a European context.

5 Rather than revisit the more or less regular stage history or provide a reinterpretation of King Lear in Marcel Proust's Le Temps Retrouvé, therefore, this paper addresses the Shakespearean interest of the British Expeditionary Force in France as well as the bitter memories they took home with them; and the fortunes of Shakespeare in then contemporary French culture, so from a French perspective.

World War I and the politico-cultural alliance between England and France created a matchless climate for Shakespeare and his work to thrive. This becomes clear, among other things, from a famous poster used to mobilize the British Expeditionary Force, recognizing a sense of identity as well as difference. In this poster, France is represented as a medieval knight in shining armour, incongruously brandishing a shield along whose edges are written the values of "Liberté," "Egalité" and "Fraternité." This pictorial representation of France obviously combines that nation's republican ideal - "Guided by faith and matchless fortitude" as in Milton's description of Oliver Cromwell ('To Oliver Cromwell', line 3) - with Shakespeare and the English nation's views of love, marriage and steadfastness as captured in Sonnet 116: "Let me not to the marriage of true minds / Admit impediments." ${ }^{4}$

7 The knight in shining armour prompts the observation that despite the sonnet reference, it is allusions to Henry $V$ that abound in the Anglo-French space of the Great War. Let us first consider several English examples. In October 1916, The Times of London published a letter to the editor by the eminent Shakespearean Sir Sidney Lee, a letter that, in part, explains this phenomenon. Much of it was a quotation from another letter Lee had received from what he termed "an English soldier on the Western front." Based "somewhere in France," this is what the soldier had written:

This is my second autumn out here, and somehow I manage to cart around my Shakespeare, and if sometimes it is left behind for a while then my memory is fairly good and I browse there. Some of those speeches in $H$. V on war are the most wonderful things - absolutely true. ${ }^{5}$ 
The image that Lee conveys of the English soldier carrying a complete Shakespeare around with him and quoting Henry $V$ from memory, is confirmed by many sources. The popularity of Henry $V$ need come as no surprise, given the fact that, as Andrew Gurr reminds us, Henry $V$ (together with Richard II) was the most popular play in Edwardian schools. ${ }^{6}$ Perhaps the best example of Henry $V$ as the staple of school drama on the eve of the war was the 1913 production of the play at the Memorial Theatre in Stratford. It was mounted by the boys from Stratford's King Edward VI School at the invitation of Frank Benson, that same patriotic actor-manager who, as soon as Britain declared war on Germany on that fateful fourth of August 1914, tirelessly performed Henry $V$ first at London's Shaftesbury Theatre and later across the country to enlist recruits, which he did rather successfully. Easily the most moving part of the Stratford story - recently reconstructed and written up by Richard Pearson of the King Edward School - is the way in which three of the actors in the production of Henry $V$ - Victor Hyatt, Herbert Jennings and his brother Henry Jennings - were to lose their lives as soldiers of the Great War, to find their graves at Bellicourt (north of Saint-Quentin), at Festubert, and at Mont-Saint-Eloi. ${ }^{7}$

Henry $V$ was by no means the only play recited or performed by the British in wartime France. Indeed, there are fascinating accounts of Romeo and Juliet, Twelfth Night, The Merchant of Venice, Hamlet, and Macbeth, all of which were played in full or in the form of selected scenes. Yet, Henry V was the most popular hero in the British Expeditionary Force, as a personage, a stage character, a memory, or an ideal. ${ }^{8}$ On occasion, Shakespeare's dramatic rendering of him served as an inspiring memory of what the English were capable of -especially in hard times. "At this moment," The Sunday Times wrote, looking back on the year known as the annus horribilis of the Great War, "when we wait almost breathlessly, and yet with calm confidence, for news and yet more news of this great battle of the Somme, it is appropriate to recall some of the great adventures of Shakespeare's men under the warrior-King Henry V on the very ground on which our men are now fighting."

The prominence of Henry $V$ is curiously borne out by the record of a BEF production of Hamlet, mounted in August 1915, again, somewhere in France, roughly "within a few hours' distance of the firing line." The press account of this impromptu amateur Hamlet is detailed and interesting, but for our present purposes the intriguing part really comes at the end, where the anonymous correspondent writes how "[ $t]$ he proceedings were brought to a close by Henry V, clothed in all his shining accoutrements before Harfleur. Flashing his great sword he cried out the famous speech before the battle: "Once more unto the breach, dear friends, once more, and so on." "The effect," the correspondent said,

was electrical. Had the bugle sounded the charge, every man would have rushed out of that building, on the instant, as he was. All the latent warrior spirit of our race seemed to leap to a flame. As we went out into the still night our hearts were stronger, our minds brighter, our courage high, and in the quiet stars above brooded the certain promise of victorious and lasting peace. ${ }^{10}$

11 Along similar lines, the great organiser of the concert parties in wartime, Lena Ashwell - the Vera Lynn of the Great War - recalled how a Canadian Colonel in northern France "burst into Henry V's speech to his soldiers, 'Once more into the breach, dear friends." ${ }^{11}$ But then again, as Ashwell duly noted, that was in Harfleur Valley, and as we know 
from Ashwell's other writings of the period, she was inclined rather to read great symbolism into the geographical coincidence of performing plays "under strange circumstances" and "on the very scene" where Shakespeare had "drawn for the world the armies of our ancestors, equally gallant, equally gay." ${ }^{12}$

R. B. Marston described this striking phenomenon of quoting Shakespeare and of alluding to the French Wars in appropriately modernist terms. In The Spectator of December 1916 he noted that: "The constant references by our officers and privates to the battlefields in France so gloriously described by Shakespeare, shows how well the wireless message from his [= Shakespeare's] mind has been caught by the men of the British Expeditionary Force." ${ }^{13}$

An observation of this kind makes better sense when we recall that the BEF's Great War action in France coincided not only with the fateful Battle of Waterloo of 1815, but also with the $500^{\text {th }}$ anniversary of the Battle of Agincourt of 1415 . Agincourt was the talk of the town, or the talk of the trenches, rather.

14 Any Shakespearean in his right mind would think that Agincourt was a potential source of embarrassment, a likely flee in the fur of any entente cordiale between England and France. Dr Johnson had been decidedly sardonic when, in the $18^{\text {th }}$ century, he suggested a performance of Henry $V$ at Versailles. And he was of the same mind as the eccentric Cincinnati-born and French-married Shakespearean, countess Clara Longworth de Chambrun, who in 1918 noted that: "It would [really] be a mistake to perform Henry $V$ or the first part of Henry VI in France, because these plays would hurt the national feelings of the French." ${ }^{14}$

Curiously, this perception was not as widely shared during the Great War as one might expect. On occasion the battle of Azincourt was used to boost the morale of the BEF, even if it required a flagrant act of reinterpreting Anglo-French history, Shakespeare's play, or both, to read it as the event that led up to the entente cordiale itself, which was considered by many to be a new, international band of brotherhood. As early as October 1914, George Russell noted:

$$
\begin{aligned}
& \text { In twelve months from now [now being October 1914] the five hundredth } \\
& \text { anniversary of the triumphant prediction will have come round, and by that } \\
& \text { time the words, already famous, will have acquired a new and an even more } \\
& \text { glorious significance. For St. Crispin's Day, 1914, finds us again "a band of } \\
& \text { brothers," but fighting shoulder to shoulder with the gallant people who } \\
& \text { once were our foes, in the most chivalrous contest which either France or } \\
& \text { England has ever undertaken. It is a moment for looking forward and for } \\
& \text { looking back. }{ }^{15}
\end{aligned}
$$

"Five centuries divide Agincourt from Mons and the Marne," another observer noted, but the battle waged then and the quarrels of the subsequent centuries had all been "milestones in the long road which had to be traversed." Henry $V$ - the play - was seen to be "working through deadly strife to earnest and honest "paction'," thus symbolising "five centuries of Anglo-French history now in happy though tragic issue."16

Given such cases of deft and ultimately also persuasive wartime revisionism, one wonders if it was very sensitive for the men of the Queen's Westminster Rifles stationed at Rouen to commemorate only the Agincourt victory by lifting three of the relevant scenes from Shakespeare's play for an actual replay of 1415. On 27 September 1915 "an entire act from Shakespeare's great play" was performed, including: 
Scene I. Agincourt (Before the Battle)

Tableau of the Battle

Scene II. Agincourt (Evening after the Battle) ${ }^{17}$

Certainly, as Thomas Barclay noted in his entente history entitled Angleterre et France of 1916, it was no longer possible for young people growing up in France at the time, to imagine a past when the prevailing hatred towards the English would ever find a proper reason to make popular a new war with England, but a bold focus in 1915 on the victory of 1415 cannot have been appreciated by all. ${ }^{18}$

To my regret, I have not been able to find more than the production program - listing Lance Corporal Herbert Maule as both director and as the actor who played Henry V so we may never know more about the contemporary impact of the play, about the live music performed by the Cavalry Y.M.C.A. Band, or about the costumes and armour rented in Rouen for the occasion. ${ }^{19}$

Fortunately, we are better informed about that other wartime production of generous scenes from Henry V staged on Tuesday 2 and Wednesday 3 May 1916. It was mounted at the Y.M.C.A.'s Kinema Hut of No. 1 Camp, "somewhere in France," and, as further research reveals, this happened to be in one of the most symbolic towns in the troubled history of Anglo-French relations, even in Henry $V$, namely Calais. It is worth taking a closer look at this production presented under the patronage of the British and Belgian base commanders at Calais, as well as the Governor and the Mayor of the town, with proceeds intended for the Star and Garter Home for Disabled Soldiers and Sailors.

Conditions for this production were, of course, far from ideal, and the various reports are really a long description of the fortunes, the misfortunes, and the near misses that are the stock in trade of the amateur theatre. In this army setting, for example, with a rehearsal time of three weeks, there were no understudies, and this was a liability when troop movements were obviously unpredictable and random. In the event, the actor playing Henry $\mathrm{V}$ received orders to move on the day of the performance itself, but, as we learn, disaster was fortunately averted.

'Henry V' achieved his objective, in communal terms, but also artistically and financially. Le Phare de Calais described the enterprise as "a truly great success" ["un très grand succès"]. ${ }^{20}$ The other local newspaper, Le Petit Calaisien wanted expressly to congratulate the organisers of this initiative, and also to thank them for allowing the citizens of Calais to celebrate what was, after all, the Shakespearean Tercentenary, with them. "The many citizens of Calais who had braved the prospect of going out to the British camp at several kilometres from the town centre," the paper noted, "had had no reason to regret their pains" ["Les nombreuses personnes qui osèrent affronter les quelques kilomètres qui séparent le centre de la ville du grand camp britannique n'eurent pas à regretter leur dérangement"]. ${ }^{21}$

Clearly, on reading about the citizens of Calais in this context, it would be naïve to continue to assume, like the Countess de Chambrun, that the play might have a disastrous impact on French audiences. As the facts about the tercentenary celebrations in Calais reveal, much else could be read and was read into the play. And directorial choices in the play's production further helped to change Henry $V$ from a play about war into a play about peace, from a history of hate into a history of love.

Henry was allowed his Act 3, scene 1, "Once more unto the breach" - but this scene was followed by the language lesson (with Princess Katherine and Alice), and by Act 5, scene 
2 (the courtship scene with the signing of the peace treaty at Troyes). The Harfleur scene, then, was balanced by scenes that furthered the rapprochement and entente between the enemy nations. Also incidentally (as one reviewer noted) this choice of scenes effectively resolved the language barrier, since these scenes "were partly in French and partly in English" already ["Ces scènes sont partie en anglais, partie en français"].22

It is true that in the eyes of one observer, Lieutenant W.J.F. Anderson Raby, the actor playing Henry V, was too serious in his interpretation, and appeared "somewhat forgetful of the humour amid the heroics of his part." ${ }^{23}$ Fortunately, though, a smart casting decision neutralised this effect. In the event, the part of Katherine was played by Marthe West, a local actress of Anglo-Calais descent. With her obvious status and her "broken English accent," West "perfectly fitted the part of Princess Katherine." ${ }^{24}$ This explains why her exchanges with Alice - played by Miss Lowson of the First Aid Nursing Yeomanry (F.A.N.Y.), "whose long silences were as eloquently acted as her few words in the royal love-scene" 25 - met with great praise.

Clearly, the production's success may be explained by its focus not on the battle but on the entente cordiale achieved with the Treaty of Troyes and the marriage of Henry and Katherine. As one observer noted, "The memories of Agincourt [were] not green enough to have caused a pang to our French visitors," ${ }^{26}$ but no risk was taken to revive these either with "la belle tragédie patriotique "King Henry V"' - as the Petit Calaisien called $i^{27}$ - "and the note of amity between the two nations, with which the play concluded," therefore, "made a fitting end to the performance," which explains why "[t]he French invited to the play were thoroughly appreciative." ${ }^{28}$

This emphasis on harmonious Anglo-French relations via Henry $V$ and on the ever endearing stories of the hazards that are the staple of the amateur thespian's existence, should not lead us to assume that the proceedings at Calais in May 1916 were altogether spontaneous. Both local newspapers described how, at the end of the evening, all members of the audience received a souvenir. It was "a very pretty brochure" printed in medieval type, containing the details of the life of Shakespeare, the background to the Tercentenary, as well as selections from the playwright's work annotated, as the Phare de Calais reported, by "M. le professeur Colianez." For "Colianez" (a name that contains three unfortunate spelling errors), we should read Gollancz). Clearly, those Calaisians who had come to see the production, undeterred by the difficulties of Shakespeare's language, were, at the end of the evening, treated to a round of pedagogical fireworks from Israel Gollancz, the Secretary of the British Academy, the inventor of "Global Shakespeare," who also happened to be the Honorary Secretary of the Shakespeare Tercentenary Committee in Britain (and much besides): Gollancz was to be knighted for his services in April 1919, to become Sir Israel Gollancz to the world, and remain "Golly" to his friends. Of course, the tercentenary celebrations at Calais were not a spontaneous expression of jingoism, but a carefully managed campaign under the aegis of the entente cordiale, meant to have the French and the English see eye to eye, now and forever. ${ }^{29}$

The "entente cordiale" displayed in Calais in 1916 permeates much of the history of Shakespeare in France during the Great War. In this history, the French themselves may not have been as apt to quote Shakespeare as frequently as their cross-Channel neighbours, but they did not remain silent. And when they turned to Shakespeare in an 
attempt to capture more accurately the Anglo-French relations of the time, they did not hesitate to quote from the A-play either, the Azincourt play, Henry V.

In 1916, the Chancellor of the University of Nancy - Charles Adam - subtly but unmistakably drew on Henry $V$ when he advised his audience to read, or rather to reread, Shakespeare in order to learn how a man might "gentle his condition" by fighting shoulder to shoulder with others: "While we wait for the great day of peace," Adam said, "we will re-read Shakespeare's lines that are in advance applicable to these epic times, [lines] in which he celebrates the glory of all those who, fighting for the good cause, become 'brothers' and who are 'ennobled."'30

It is in accordance with this same fraternizing tendency that we may understand the way in which - in the run-up to the Dardanelles campaign of 1915 (when matters still looked favourable) - both the English and the French repeatedly quoted King Henry the Fifth's famous question to Katherine in Act 5, scene 2: "Shall not thou and I, between Saint Denis and Saint George, compound a boy half French, half English, that shall go to Constantinople and take the Turk by the beard?" ${ }^{31}$

In the first part of this paper, I have tried to show the bilateral relations between England and France and the prominence of "Shakespeare" in this alliance. The second part of this paper looks at the impact of that same war on France, expressed also via the nation's engagement with Shakespeare, though not via Henry $V$ this time, but with another play, Hamlet.

In my perception one of the most impressive and hence also lasting cultural traces of the Anglo-French entente for us in Shakespeare studies remains Paul Valéry's two-part essay on Hamlet and Europe of 1919. In the essay, now known as "The Crisis of the European Mind," first published in the London Athenaeum in 1919 - and so a welcome manifestation of the Anglo-French entente that is central to my paper today - we read:

From an immense terrace of Elsinore which extends from Basle to Cologne, and touches the sands of Nieuport, the marshes of the Somme, the chalk of Champagne, and the granite of Alsace, the Hamlet of Europe now looks upon millions of ghosts. But he is an intellectual Hamlet. He meditates upon the life and death of truths. [...] If he picks up a skull, it is a famous skull. [...] Hamlet hardly knows what to do with all these skulls. ${ }^{32}$

These observations by Valéry's Hamlet translated the French author's traumatized post-World War I vision into a stark and complex image. It is an image that has very much become part of our current thinking about Europe and European culture. This is why, for example, they eventually came to fuse into the opening lines of Heiner Müller's Hamletmaschine: "I was Hamlet. I stood at the shore and talked with the surf BLABLA, the ruins of Europe in back of me." ${ }^{33}$ They also, of course, inspired Jacques Derrida's influential Spectres of Marx, whose concept of "ghosting" has since become a buzzword in academe worldwide. ${ }^{34}$ What concerns me here is that our tendency to focus on Valéry's European ambitions, has blinded us to the true origins of the Hamlet appropriation that we are witnessing. Valéry's image of Hamlet, of course, goes back to the nineteenth century German poet Ferdinand Freiligrath, but there is an even stronger French influence here at work that has gone entirely unnoticed.

33 Let us begin by looking at the actual text of "The Crisis of the Spirit" essay - first published in the London Athenaeum. It seems to me that we should all recognize that 
the work which Middleton Murry commissioned appeared emphatically not as "The Crisis of the Mind" - as we find it anthologized today - but under the title: "The Spiritual Crisis of France." Next, when we go to the text and keep in mind the Athenaeum title, don't we find that the Europe which Valéry's Hamlet describes is largely located to the west of the Basle-Cologne line? Surely, Hamlet's gaze leaves out Germany, with the exception - appropriately - of the Rhineland. To insist that there is a European and not a French core to Hamlet's gaze in the essay, we would be committing a mental error comparable to John of Gaunt's in Richard II who said 'This England' and really meant 'This Britain.' Is not what later readers have interpreted as the landscape of "Europe" sketched by Hamlet in Valéry's essay, is not that landscape best defined as "Somewhere in France"?

Having looked at the original text and title of "The Crisis of France" and at the latent Gallo-centrism that it reveals in terms of its gaze, let us also consider the broader cultural contexts of Valéry's Shakespeare appropriation. These also suggest that his image of Hamlet was very much a native, French invention, although this is not to say that it was not also prompted by other German and British uses of the Shakespearean character in the political arena.

It all started in that fateful summer of 1914, when both the German Emperor and the Chief of the Austro-Hungarian General Staff, Conrad von Hötzendorff perceived the Balkan crisis that led to the Great War as an existential crisis - or, as von Hötzendorff himself put it, as "a matter of 'to be or not to be." ${ }^{35}$ And soon after the outbreak of the War, the German propaganda machine brought postcards onto the market, spreading the same philosophy: "Um sein oder nicht sein handelt es sich" - "To be or not to be, that's what it's all about." 36

Interestingly, the Emperor's Hamlet-like attitude invited an immediate response from the French press. As early as 11 August 1914 - barely over a week into the war - the right-wing La Croix devoted a short article to the German appropriation of "Être ou ne pas être." ${ }^{37}$ Apparently, the paper commented, the German emperor, "taking up arms against a world of enemies," had found it necessary to quote from Hamlet. But should he not, instead, have quoted something like: "There's something rotten in Germany; it is the German himself who has committed horror and barbarism"?

This early French response to the emperor's personal brand of Hamletism in 1914 was not the last. When the German army suffered any significant losses, the French media were sure to make the emperor eat even his Shakespearean words, and this is where the image emerges that we find in Valéry's essay. Now, Wilhelm II was shown as Hamlet, addressing a skull in a typical Prussian spike helmet, with the words: "Être ou ne plus être ..." (“To be or no longer to be?"). The illustration originally appeared on the front page of the Echo de Paris on 20 August 1915, and it was soon given wider and more lasting circulation by the popular reader's digest journal, Messidor. ${ }^{38}$

Naturally, the phrase "To be or not to be" was popular in France also before the First World War. But the application of phrases and images to comment on the impact of the First World War - as we also see happening in Paul Valéry's famous utterances - was unique. It was unique not only because a specific moment in history gave various strands of Shakespeare's play a new lease of life abroad, but also because of its remarkable popularity.

It is most likely that the Anglo-French entente and the experience of the English in France contributed to this effect as much as the propaganda of the Hamletian Emperor, 
quoting 3.1, again and again. For example, following the significant British capture of the German salient at Fricourt (during the Battle of the Somme in July 1916), Stratfordbased cartoonist and ancien combattant Bruce Bairnsfather depicted a Tommy addressing not a skull, or a helmet, but a German cap with the words: "Alas! Poor Herr Von Yorick!" ${ }^{39}$

A preoccupation with Hamlet - posing his existential questions in the famous soliloquy, and reflecting on the skull of his mentor - neatly fitted a wartime tradition in which the phrase "Yorick's Own" was coined, a phrase, though, that has disappeared from circulation since, and which only survives in the World War I history of the Red Cross, written by that eminent playwright, director and truly stunning Shakespearean, Harley Granville Barker: “'Yorick's Own' - Barker wrote - “'Yorick's Own' is the Graves Registration Commission. You must not make too free with its nickname unless you know it well, for it is a full-blown, and dignified section of the British Army." 40

41 There are many more examples, but let us return to the French manifestations. In the spring of 1916, the British Government passed the Military Service Act, introducing conscription. The French journal Le Rire reflected on the Act in a cartoon - "d'après Shakespeare" - which expressed the view that more British soldiers on a regular basis in France spelled serious trouble for the Germans. Hence, the British officer, like a present-day Hamlet, is made to address the same skull and spike helmet that we saw the Emperor study earlier. The Briton speaks the memorable words: "Alas! Poor Bochy!"41

In France, Shakespeare's Hamlet lent itself well for satirical and propaganda purposes, but it was also used towards more serious ends. One final example is the Offertoire, a collection of sketches written by Fernand Pignatel while on duty in the trenches in 1918, a collection of sketches illustrated by his companion, Pierre Gerbaud. One of the engravings, entitled "Hamlet," is accompanied by the text "To be or not to be." 42

With these examples from Hamlet we have moved beyond the Armistice of 1918 and the Versailles Treaty of 1919, the year that witnessed the publication of Valéry's essay on the crisis of the French spirit, an essay with, at its centre, not an image that excels in terms of originality, perhaps, but certainly one that unusually for Valéry, conveys a pervasive popular French sentiment.

The Great War and the political alliance between England and France created a matchless climate in which Shakespeare and his work thrived. The concurrence of the entente cordiale and the political alliance produced a unique moment in European history, demonstrating how, among other things, Shakespeare could function as a national, a supranational, or a European genius.

Moving through the years, I have looked at a number of events from the perspective of the British, and a number of uses from the French perspective, though aware throughout that all of these manifested themselves at the time of the entente. In the first part of my paper, I have tried to demonstrate how cultural and political relations between Britain and France at the time gave rise to the rather unexpected refashioning of a high-bred warhorse like Henry $V$ in order to accommodate the self-image and the shared ideals of both historic nations. In the second part of my paper, I have tried to demonstrate that what we have come to praise as one of the foundational texts of Europe - Valéry's famous two-part Hamlet essay of 1919 - may still tell us more about the popular experience of Shakespeare in France, both in terms of wartime rhetoric, and in terms of grief, and thus also benefit the expanding branch of European 
Shakespeare. For our research into the rich cultural history of Shakespeare and the entente cordiale has only just begun.

\section{NOTES}

1. For a valuable summary of political relations, see David Dutton, "Britain and France at War, 1914-1918", in Anglo-French Relations in the Twentieth Century, Alan Sharp and Glyn Stone, eds., London and New York, Routledge, 2000, p. 71-88.

2. Jonathan Rose, The Literary Churchill: Author, Reader, Actor, New Haven and London, Yale University Press, 2014.

3. Recent contributions to the field include See Eva Krivanec, Kriegsbühnen: Theater im Ersten Weltkrieg. Berlin, Lissabon, Paris und Wien, Bielefeld, transcript Verlag, 2012, and Martin Baumeister, Kriegstheater. Großstadt, Front und Massenkultur, 1914-1918, Essen, Klartext Verlag, 2005.

4. See http://libx.bsu.edu/cdm/search/collection/WWIPosters/ under 'Shakespeare'.

5. The Times 30 October 1916.

6. Henry V, ed. Andrew Gurr, New Cambridge Shakespeare, Cambridge, CUP, 1992, p. 46.

7. Richard Pearson, The Boys of Shakespeare's School in the First World War, Stroud, The History Press, 2010.

8. Paul Fussell, The Great War and Modern Memory, Oxford, OUP, 1975, and Mark Girouard, The Return to Camelot: Chivalry and the English Gentleman, New Haven and London, Yale University Press, 1981, p. 275-93.

9. The Sunday Times 31 December 1916, basing itself on R. B. Marston's story in The Spectator, 30 December 1916, p. 6.

10. "Hamlet at the Front: Impromptu Acting by a Khaki Company", The Times, 24 August 1915, p. 9. Morale boosting with Henry V could also be directed to those at home. In 1916, Eric Williams presented his Henry V-based picture England's Warrior King at the West-End Cinema in London. He would recite to the images from the play on-screen. In the case of his Henry V movie, the cast was "drawn from the ranks of the Royal Scots Greys [then] fighting at the front." See The Sunday Times, 30 April 1916, p. 14; Julie Brown and Annette Davison, The Sounds of the Silents in Britain, Oxford, OUP, 2013.

11. Lena Ashwell, Modern Toubadours: A Record of the Concerts at the Front, Copenhagen, Gyldendal, 1922, p. 141-42.

12. Quoted in Margaret Leask, Lena Ashwell: Actress, Patriot, Pioneer, Hatfield, University of Hartfordshire Press, 2012, p. 136.

13. The Spectator, 30 December 1916, p. 9.

14. C. Longworth de Chambrun, "Deux pièces de Shakespeare: Antoine et Cléopâtre - Le Marchand de Venise," La Revue de Paris, 1918, p. 650.

15. George W. E. Russell, The Spirit of England, New York, E. P. Dutton \& Company, 1915, p. 110-111. 16. Edward Salmon, "Henry V", The Academy, January 1915, p. 11.

17. C. Moore papers at The Brotherton Library, Leeds, UK, Liddle Collection, LIDDLE/WW1/GS/ 1139.

18. Thomas Barclay, Angleterre et France: Fraternité en guerre / Alliance dans la paix, with a foreword by Gabriel Hanotaux, Pages Actuelles 1914-1916, No. 91, Paris and Barcelona, Bloud et Gay, 1916, p. 8. 
19. See C. Moore papers at The Brotherton Library above.

20. Le Phare de Calais, 6 May 1916.

21. Le Petit Calaisien, 6 May 1916.

22. Ibid.

23. "Cambridge at Calais," The Cambridge Magazine, 3 June 1916 (p. 513).

24. Ibid.

25. Ibid.

26. Ibid.

27. Le petit Calaisien, 6 May 1916.

28. "Cambridge at Calais," op. cit., p. 513.

29. Le Phare de Calais (8 June 1916) reported, after all expenses had been paid (FF 727.30), 1,107.70 remained for the "Star and Garter Home for disabled Soldiers and Sailors."

30. "En attendant le grand jour de la paix, nous relirons les vers de Shakespeare qui s'appliquent si bien par avance à l'épopée actuelle, lorsqu'il célèbre la gloire de tous ceux qui, combattant pour la bonne cause, deviennent 'autant de frères', et sont tous annoblis" (Ch. Adam, Commémoration de Shakespeare. Aux Universités d'Angleterre, d'Écosse et d'Irlande, Nancy, 1916. BL Ac. 382.b [1]). I am grateful to Clara Calvo for drawing my attention to this.

31. Nouvelles de France, 7 September 1916, p. 195.

32. Paul Valéry, "Letters from France”, I: “The Spiritual Crisis", The Athenaeum, 1919, 365-368, p. 368-369.

33. Hamletmachine, in Adaptations of Shakespeare: A Critical Anthology of Plays from the Seventeenth Century to the Present, Daniel Fischlin and Mark Fortier, eds., London and New York, Routledge, 2000, p. 211.

34. See Richard Wilson's Shakespeare in French Theory: King of Shadows, London and New York, Routledge, 2007. Cf. Jacques Derrida: "the European Hamlet looks at thousands of specters" (Spectres of Marx, 4).

35. Fritz Fischer, War of Illusions: German Policies from 1911 to 1914, New York, W. W. Norton \& Co., 1975, p. 395. See also Keith Wilson, "Hamlet - with and Without the Prince: Terrorism at the Outbreak of the First World War", The Journal of Conflict Studies, Winter 2007, 22-41.

36. A copy of the postcard is available online at the University of Osnabrück: http:// www.bildpostkarten.uni-osnabrueck.de/displayimage.php?pos=-1592.

37. La Croix, 11 August 1914, p. 3.

38. L'Echo de Paris, 20 August 1915, p. 1; La Grande Guerre par les grands écrivains. Messidor 22 (5 December 1915), 704.

39. Captain Bruce Bairnsfather, Fragments From France, New York and London, G. P. Putnam's Sons and The Knickerbocker Press, n.d. [= c.1917], p. 115. One is not inclined to think of Bairnsfather as a propaganda cartoonist, but the Hamletian glee over German losses does direct attention away from the fact that on this occasion the XV Corps had more than 8,000 casualties, the 10th Battalion West Yorkshire Regiment had 733 casualties, the worst loss of any of the battalions engaged on the first day.

40. [Harley] Granville Barker, The Red Cross in France, with a preface by Frederick Treves, London, Hodder and Stoughton, 1916, p. 78.

41. Le Rire, 20 May 1916.

42. Fernand Pignatel, L'Offertoire: Trente scènes du calvaire du poilu, illustrated by Pierre Gerbaud, Paris, Etienne Chiron, 1921, p. 13-14. 


\section{ABSTRACTS}

This paper explores the various ways in which the entente cordiale and the political alliance between France and England in 1914-1918 created a unique climate in which the reception of Shakespeare thrived on either side of the Channel. Studying a number of manifestations during the period, we learn that Shakespeare could be a national hero for the English, but at the same time also a supranational hero shared by the two nations. Tracing the ways in which England and France cherished their Shakespeare during the period, this paper also makes a case for exploring the long-neglected presence of Shakespeare in French popular culture.

Cet article explore les différentes façons dont l'entente cordiale et l'alliance politique entre la France et l'Angleterre pendant la Première Guerre Mondiale ont créé un climat favorable à la réception de Shakespeare des deux côtés de la Manche. L'étude de plusieurs manifestations culturelles pendant cette période nous apprend que si Shakespeare était un héros national pour les Anglais, il a aussi pu incarner un héros supra-national commun aux deux nations. Il s'agit donc d'étudier la présence de Shakespeare dans la culture populaire non seulement en Angleterre mais aussi en France, domaine longtemps négligé.

\section{INDEX}

Keywords: Entente cordiale, Gollancz Israel, Hamlet, Henry V, Longworth de Chambrun Clara, popular culture, Shakespeare in performance, Valéry Paul, World War I

Mots-clés: Culture populaire, entente cordiale, Gollancz Israel, Hamlet, Henry V, Longworth de Chambrun Clara, Valéry Paul, Première Guerre Mondiale, représentations scéniques de Shakespeare

\section{AUTHOR}

\section{TON HOENSELAARS}

Utrecht University 